\title{
Hematological parameters and total plasma protein values of captive strigiformes occurring in Brazil
}

\section{Parâmetros hematológicos e valores de proteínas plasmáticas totais de Strigiformes cativos de ocorrência no Brasil}

\author{
Miúriel de Aquino Goulart ${ }^{1 *}$; Frederico Fontanelli Vaz²; Marília de Oliveira Koch; \\ Carlos Czpak Kroetz; ${ }^{4}$ Rosangela Locatelli Dittrich ${ }^{5}$
}

\section{Highlights:}

Raptors are important environmental quality indicators.

There is a lack of studies about clinical pathology of raptors published in Brazil.

Hematological database and total plasma protein values for healthy Brazilian adult owls.

To improve laboratorial diagnosis of owls in Brazil.

\begin{abstract}
Brazil has the highest number of birds of prey in the world, which are important environmental quality indicators. Nevertheless, few studies of the clinical pathology of raptors have been developed in this country. The objectives of this study were to create a database of owl hematology in Brazil and to compare the values between sex in Asio clamator, Megascops spp. and Tyto furcata. Blood samples were collected from 81 captive owls of 10 species located in Rio Grande do Sul, Santa Catarina, Paraná and São Paulo states, Brazil. Hemogram and Total Plasma Protein (TPP) values were determined. Reference intervals (RIs) and descriptive statistic values were established using an Excel program with Reference Value Advisor. The reference intervals were the following: A. clamator: $\mathrm{RBC}\left(\times 10^{6} / \mu \mathrm{L}\right) 1.0-2.5$; PCV (\%) 30.2-50.1; $\mathrm{Hb}\left(\mathrm{g} \mathrm{dL}^{-1}\right)$ 6.7-15.3; $\mathrm{MCV}$ (fL) 123.8-355.2; MCHC (\%) 17.1-38.6; WBC $\left(\times 10^{3} / \mu \mathrm{L}\right)$ 1.2-23.6; Heterophils $\left(\times 10^{3} / \mu \mathrm{L}\right)$ 0.6-16.6; Lymphocytes $\left(\times 10^{3} / \mu \mathrm{L}\right) 0.6-10.2$; Eosinophils $\left(\times 10^{3} / \mu \mathrm{L}\right)$ 0.0-1.9; Basophils $\left(\times 10^{3} / \mu \mathrm{L}\right)$ 0.0-1.0; Thrombocytes $\left(\times 10^{3} / \mu \mathrm{L}\right) 10.8-56.6 ; \mathrm{H} / \mathrm{L}$ 0.0-10.8. Megascops spp.: RBC $\left(\times 10^{6} / \mu \mathrm{L}\right)$ 0.8-2.3; PCV (\%) 29.7-44.6; $\mathrm{Hb}\left(\mathrm{g} \mathrm{dL}^{-1}\right)$ 6.4-12.4; $\mathrm{MCV}(\mathrm{fL}) 131.6-374.4 ; \mathrm{MCHC}$ (\%) 12.1-34; WBC $\left(\times 10^{3} / \mu \mathrm{L}\right)$ 0.7-23.1; Heterophils $\left(\times 10^{3} / \mu \mathrm{L}\right) 1.1-10.3$; Lymphocytes $\left(\times 10^{3} / \mu \mathrm{L}\right) 0.0$ 11.5; Eosinophils $\left(\times 10^{3} / \mu \mathrm{L}\right) 0.0-2.2$; Basophils $\left(\times 10^{3} / \mu \mathrm{L}\right) 0.0-0.7$; Thrombocytes $\left(\times 10^{3} / \mu \mathrm{L}\right) 10.3-43.6$; H/L 0.5-7.3; TPP $\left(\mathrm{g} \mathrm{dL}^{-1}\right)$ 2.9-5.1. The parameters for Tyto furcata were presented with descriptive statistics values. Individual data were provided for the others Strigiformes species sampled. This study provides a wide database of hematological and TPP references for Megascops spp., A. clamator and T. furcata and hematological values for Athene cunicularia, Bubo virginianus, Pulsatrix perspicillata, Asio stygius, Pulsatrix koeniswaldiana, Strix virgata and Asio flammeus in Brazil.
\end{abstract}

Key words: Birds of Prey. Blood parameter. Owls. Raptors.

\footnotetext{
1 Discente do Curso de Doutorado do Programa de Pós-Graduação em Ciências Veterinárias, Universidade Federal do Rio Grande do Sul, UFRGS, Porto Alegre, RS, Brasil. E-mail: miuriel.vet@gmail.com

2 Dr. em Patologia Experimental e Comparada, Universidade de São Paulo, USP, São Paulo, SP, Brasil. E-mail: fredfontanelli@ yahoo.com.br

3 Dr ${ }^{\mathrm{a}}$ em Ciências Veterinárias, Universidade Federal do Paraná, UFPR, Curitiba, PR, Brasil. E-mail: mariliakoch@hotmail.com

4 M.e em Ciência Animal, Universidade do Estado de Santa Catarina, UDESC, Lages, SC, Brasil. E-mail: kkroetz@hotmail.com

5 Prof ${ }^{a}$, Departamento de Medicina Veterinária, UFPR, Curitiba, PR, Brasil. E-mail: roslocdi@ufpr.br

Author for correspondence
}

Received: July 01, 2019 - Approved: Mar. 26, 2020 


\section{Resumo}

O Brasil tem o maior número de aves de rapina do mundo, e estas aves são, como topo de cadeia alimentar, importantes indicadores de qualidade ambiental. No entanto, poucos estudos sobre a patologia clínica de rapinantes foram desenvolvidos no Brasil. Os objetivos deste estudo foram criar uma base de dados para hematologia de corujas no país e comparar os valores entre sexos em Asio clamator, Megascops spp. e Tyto furcata. Amostras de sangue foram coletadas de 81 corujas em cativeiro, de 10 espécies diferentes, localizadas nos estados do Rio Grande do Sul, Santa Catarina, Paraná e São Paulo, Brasil. Foi determinado o hemograma e as proteínas plasmáticas totais (PPT). Os intervalos de referência (IR) e os valores de estatística descritiva foram estabelecidos através da utilização do Excel com o suplemento do Reference Value Advisor. Os IR foram os seguintes: A. clamator: Eritócitos (x10 $76 / \mu \mathrm{L}) 1.0-2.5$; $\mathrm{Ht}(\%)$ 30.2-50.1; Hb (g/dL) 6.7-15.3; VCM (fL) 123.8-355.2; CHCM (\%) 17.1-38.6; Leucócitos (x10/ $\mu \mathrm{L})$ 1.2-23.6; Heterófilos $\left(\mathrm{x} 10^{3} / \mu \mathrm{L}\right)$ 0.6-16.6; Linfócitos $\left(\mathrm{x} 10^{3} / \mu \mathrm{L}\right)$ 0.6-10.2; Eosinófilos $\left(\mathrm{x} 10^{3} / \mu \mathrm{L}\right) 0.0$ -

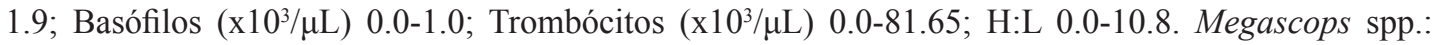
Eritócitos (x10\%/ $\mu \mathrm{L})$ 0.8-2.3; Ht (\%) 29.7-44.6; Hb (g/dL) 6.4-12.4; VCM (fL) 131.6-374.4; CHCM (\%) 12.1-34; Leucócitos (x103/ $\mu \mathrm{L})$ 0.7-23.1; Heterófilos $\left(\mathrm{x} 10^{3} / \mu \mathrm{L}\right) 1.1-10.3$; Linfócitos $\left(\mathrm{x} 10^{3} / \mu \mathrm{L}\right) 0.0-11.5$; Eosinófilos $\left(\mathrm{x} 10^{3} / \mu \mathrm{L}\right)$ 0.0-2.2; Basófilos $\left(\mathrm{x} 10^{3} / \mu \mathrm{L}\right)$ 0.0-0.7; Trombócitos $\left(\mathrm{x} 10^{3} / \mu \mathrm{L}\right)$ 10.3-43.6; H:L 0.57.3; PPT (g/dL) 2.9-5.1. Os parâmetros para Tyto furcata foram apresentados com valores de estatística descritiva. Para as outras espécies de Strigiformes amostradas, os valores individuais foram incluidos. Este estudo forneceu uma ampla base de dados de valores hematológicos e de proteínas plasmáticas totais para Megascops spp., A. clamator e T. furcata e valores hematológicos para Athene cunicularia, Bubo virginianus, Pulsatrix perspicillata, Asio stygius, Pulsatrix koeniswaldiana, Strix virgata e Asio flammeus no Brasil.

Palavras-chave: Aves de rapina. Corujas. Parâmetros sanguíneos. Rapinantes.

\section{Introduction}

One thousand and ninety-one bird species are recognized as occurring in Brazil according to the latest Brazilian Committee of Ornithological Records (Comitê Brasileiro de Registros Ornitológicos [CBRO], 2014). Five percent (99/1901) of all species in Brazil are raptors, and $23 \%$ (23/99) are owls. Two Strigiformes species are in the current National List of Wildlife Endangered Species: Pulsatrix perspicillata pulsatrix and Strix huhula albomarginata (Ministério do Meio Ambiente [MMA], 2014). These birds are at risk because of natural habitat invasion, which damages the conservation of the entire ecosystem ( Instituto Chico Mendes para Conservação da Biodiversidade [ICMBio], 2008). Raptors are important environmental quality indicators as they are at the top of the food chain (Cooper \& Forbes, 1986; ICMBio, 2008).

An important part of fauna conservation is to provide the appropriate treatment and rehabilitation to the animals directed to veterinary care. The reference values allow interpretation of the patient's health. The comparison with healthy population data provides valuable information for diagnosis and prognosis (Jones, Arheart, \& Cray, 2014; Cray, 2015). Few studies into the clinical pathology of raptors have been developed and published in Brazil (Zwarg, 2010). The lack of data, reference values and the limited sample numbers of studies already published hamper the clinical diagnosis of sickness and the health monitoring of raptors (Ammersbach, Beaufrère, Rollick, \& Tully, 2015a; Cray, 2015). So, it is necessary to compare the test results with literature data for other species and/or other conditions. However, the literature suggests to use species-specific data, and the extrapolation of species is considered inappropriate even if they are taxonomically close (Ammersbach et al., 2015a,b).

The purpose of this study was to establish a hematological and total plasma protein (TPP) database for healthy adult owls of 10 species from Brazil and compare these values between genders. 


\section{Material and Methods}

The Animal Use Ethics Committee of the Agricultural Sciences Campus of the Federal University of Paraná, Southern Brazil (protocol 027/2014) and the Biodiversity Information and Authorization System - SISBIO, Ministry of Environment (protocol 44355-6), authorized this study.

The research was conducted in the cities of Porto Alegre and Canoas (Rio Grande do Sul, n = 8), Curitiba, Tijucas do Sul and Pontal do Paraná (Paraná State, $\mathrm{n}=47$ ) and Sorocaba (São Paulo State, $\mathrm{n}=26$ ); thus, 81 animals.

The birds used in this study were from captivity in zoos, wildlife keepers, falconry companies or individual falconers, sorting centers for wild animals and/or free-living individuals, kept in veterinary hospitals/clinics for care and/or awaiting allocation/ release. Concerning the animals' diets, the protocols included feeding with rats, mice and/or quail and chicks from aviaries and/or cattle or pork meat with commercial vitamin-mineral supplementation according to each facility protocol.

Ten Strigiformes species (Asio clamator, Asio flammeus, Asio stygius, Athene cunicularia, Bubo virginianus, Megascops spp., Pulsatrix koeniswaldiana, Pulsatrix perspicillata, Strix virgata and Tyto furcata) were sampled, totaling 81 blood samples, collected from August 2014 to September 2015.

The birds were manually restrained for clinical examination, and blood sample collection was completed within $10 \mathrm{~min}$. The samples were collected from the brachial vein, medial metatarsal vein or right jugular vein according to the size of the specimen in 1- or 3-mL syringes (BD, Juiz de Fora-MG-Brazil) with $23 \mathrm{G}$ or $26 \mathrm{G}$ hypodermic needles pretreated with 1000 IU sodium heparin. The heparinization process followed that described by Santos and Cubas (2017), lubricating the syringe and the needle with anticoagulant.
The blood smears on glass slides were prepared immediately after collection. These procedures were performed by the same veterinarian. All samples were kept in tubes (Eppendorf, Hamburg, Germany) refrigerated on ice and sent to the Veterinary Clinical Pathology Laboratory of the Federal University of Paraná (Curitiba, Paraná, Brazil), within $24 \mathrm{~h}$.

Hematological variables included red blood cell (RBC) count, packed cell volume (PCV), hemoglobin (HGB) concentration, mean corpuscular volume (MCV), mean corpuscular hemoglobin concentration (MCHC), total and differential white blood cell (WBC) count, and heterophil/lymphocyte $(\mathrm{H} / \mathrm{L})$ ratio. The $\mathrm{PCV}$ was determined by the microhematocrit method (Inbras, Jardinópilis, Brazil) by centrifugation at $12,000 \mathrm{~g}$ for $5 \mathrm{~min}$; HGB concentration was determined by the cyanmethemoglobin method (Labtest kit; Lagoa Santana, MG,Brazil) in a semi-automated hematology analyzer (Mindray BA-88A; Shenzhen, Yué, China) after centrifugation of lysates (Zinkl, 1986). The RBC and WBC counts were performed by the same person in a Neubauer hemocytometer chamber using blood diluted 1:100 in 2\% solution of brilliant cresyl blue (Laborclin, Pinhais, Brazil) (Walberg, 2001). The leukocyte differential count was performed on a total of $100 \mathrm{WBCs}$ on blood smears stained with Wright's stain. Total plasma protein (TPP) was determined using an optical refractometer with temperature compensation (Instrutherm, São Paulo, Brazil).

The Polymerase Chain Reaction (PCR) testing was performed to determine the sex of samples from the Megascops spp., A. clamator and $T$. furcata species. The samples of RBC concentrate remaining from centrifugation were forwarded to the Agricultural Support Fitogen Service LTDA laboratory for testing. The primers (MP, NP and P2) used to amplification and the protocol were described by Ito, Sudo-Yamaji, Abe, Murase, \& Tsubota (2003). 
Inclusion criteria were defined as follows: all animals presented good health, were adults, were not undergoing treatments and did not present signs of illness on clinical examination and hematological evaluation.

Reference intervals (RIs) were determined using an Excel (Excel; Microsoft Corp., Redmond, WA, USA) spreadsheet with the Reference Value Advisor (version 2.1) set of macroinstructions, which performs computations following the IFCCCLSI recommendations suggested by the ASVCP guidelines (Friedrichs et al., 2010; Geffré, Concordet, Braun, \& Trumel, 2011). The calculations included descriptive statistics (sample size, mean, median, standard deviation, and minimum and maximum values) and the Anderson-Darling normality test with Box-Cox transformations. Dixon-Reed and Tukey's tests were applied to detect outliers (histograms). The RIs were calculated according to the distribution of the reference data, obtained by parametric and robust methods, whether or not data had undergone transformation. Data with non-normal distribution after data transformation by Reference Value Advisor were analyzed by nonparametric technique on $\mathrm{R}$ software (Bootstrap method and confidence interval). The RIs were calculated for the species with $n>20$. When the sample number was $<10$, all individuals' values were reported. Although the Quality Assurance and Laboratory Standards Committee do not recommend its report as providing reference values due to lack of data (Friedrichs et al., 2010), it was necessary to report the values found to reach the study objectives and to provide tools for assessing species-specific health.

The monocyte values of Megascops spp. and A. clamator did not show normal distribution, even after Box-Cox transformation. Therefore, a nonparametric test (Bootstrap) was used to establish viable parameters. It was not possible to use the same test for all non-normal distribution parameters due to the small numbers of other species $(n<23)$. We include descriptive statistics in the tables in those cases.
The comparison between sexes was done using Portal Action 2.6 with $\mathrm{p}<0.05$. Normal distribution was verified by the Shapiro-Wilk test. Values that were normally distributed were compared by Student's t-test. Nonparametric values were compared by the Mann-Whitney-Wilcoxon test.

\section{Results}

A total of 81 blood samples were collected from owls and included in the study. Samples were obtained from 10 different species: 24 ScreechOwls, 21 Striped Owls, 18 American Barn Owls, 7 Burrowing Owls, 3 Spectacled Owls, 2 Stygian Owls, 2 Great Horned Owls, 2 Tawny-browed Owls, 1 Mottled Owl and 1 Short-eared Owl. The results of PCR sexing revealed $37 \%$ (30/81) of the birds were males, $39.5 \%(32 / 81)$ females and $23.5 \%(19 / 81)$ remained unknown. Tables $1-5$ show the hematological and TPP variables obtained from adult Strigiformes from Brazil.

Outlier data were excluded for A. clamator TPP, Megascops eosinophils and T. furcata monocytes and thrombocytes. The RIs were made for the species with $\mathrm{n}>20$ : A. clamator and Megascops spp. Since for $T$. furcata $\mathrm{n}=18$, the RI was not calculated. When $\mathrm{n}<10$ (A. flammeus, A. stygius, A. cunicularia, $B$. virginianus, $P$. koeniswaldiana, $P$. perspicillata and $S$. virgata), all individuals' values are reported in the tables.

Brazil has six species of the genus Megascops. Three of them occur in regions covered by this study: Megascops atricapilla, Megascops choliba and Megascops sanctaecatarinae. The morphological differentiation between them is difficult and voicing is the most reliable way to infer the species. Therefore, Megascops spp. was used to refer to these owls as their species differentiation was difficult to perform.

Tables 6-8 show the hematological mean values ( $\pm \mathrm{SD}$ ) according to sex of A. clamator, Megascops spp. and T. furcata. 


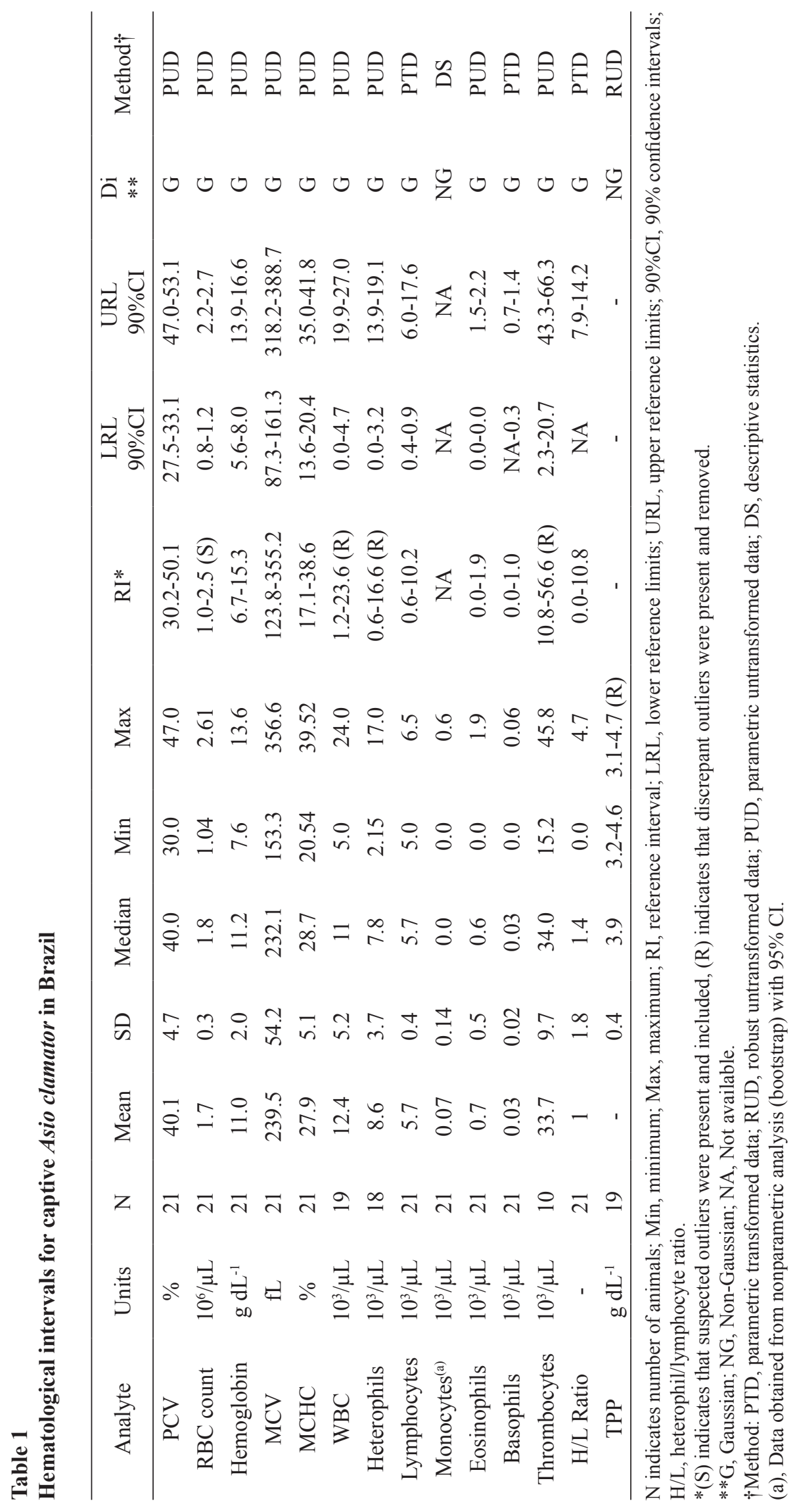

Semina: Ciências Agrárias, Londrina, v. 41, n. 5, suplemento 1, p. 2129-2142, 2020 


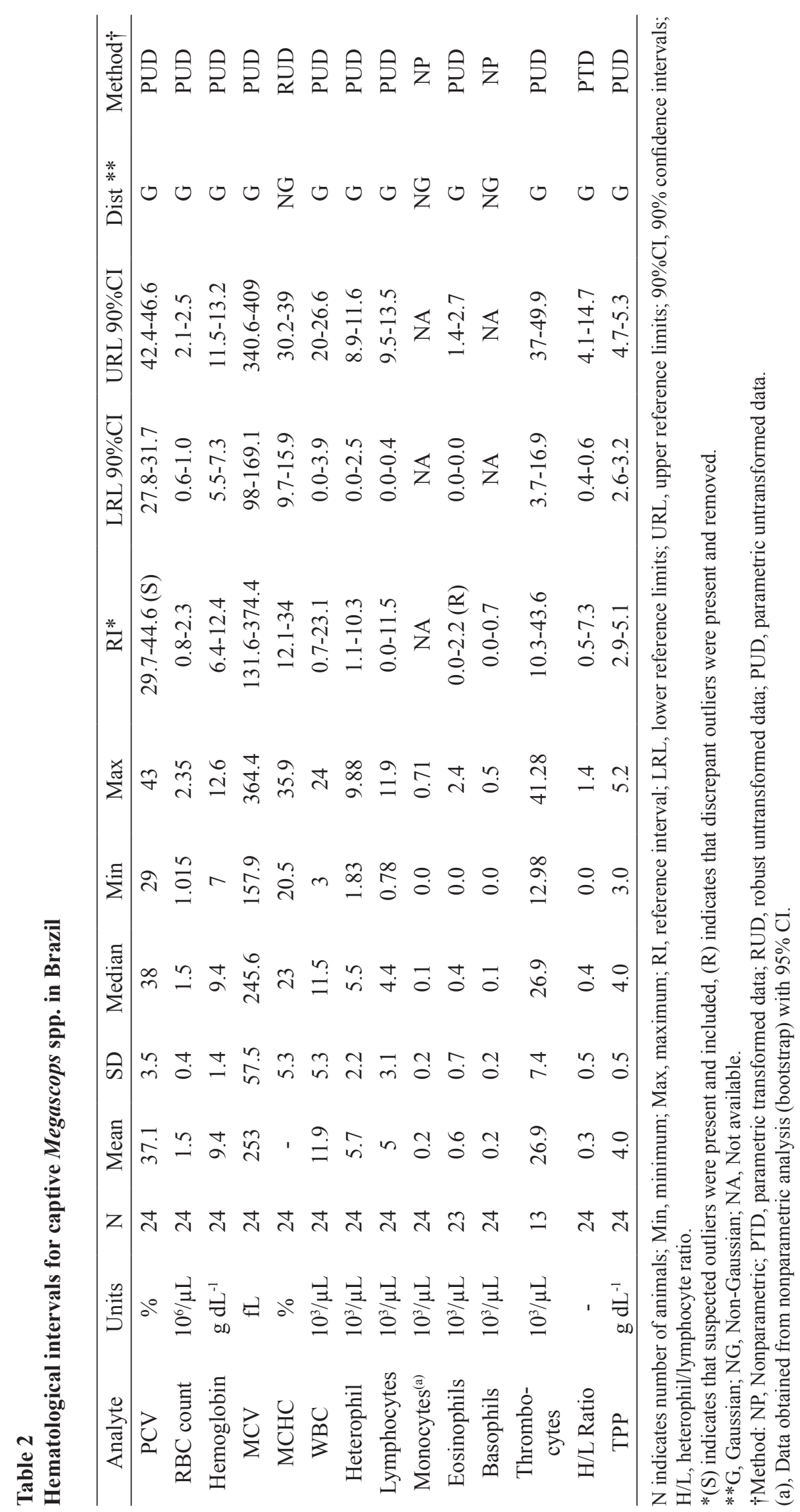




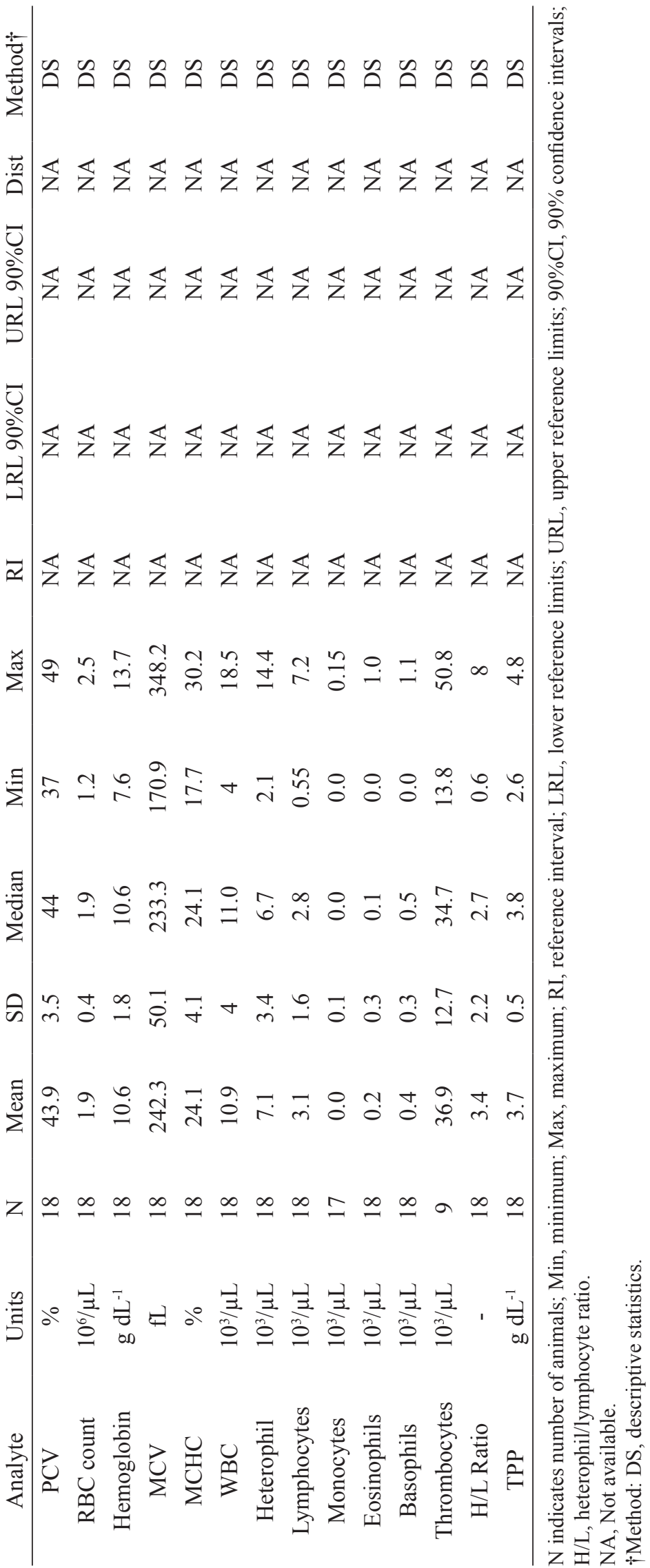




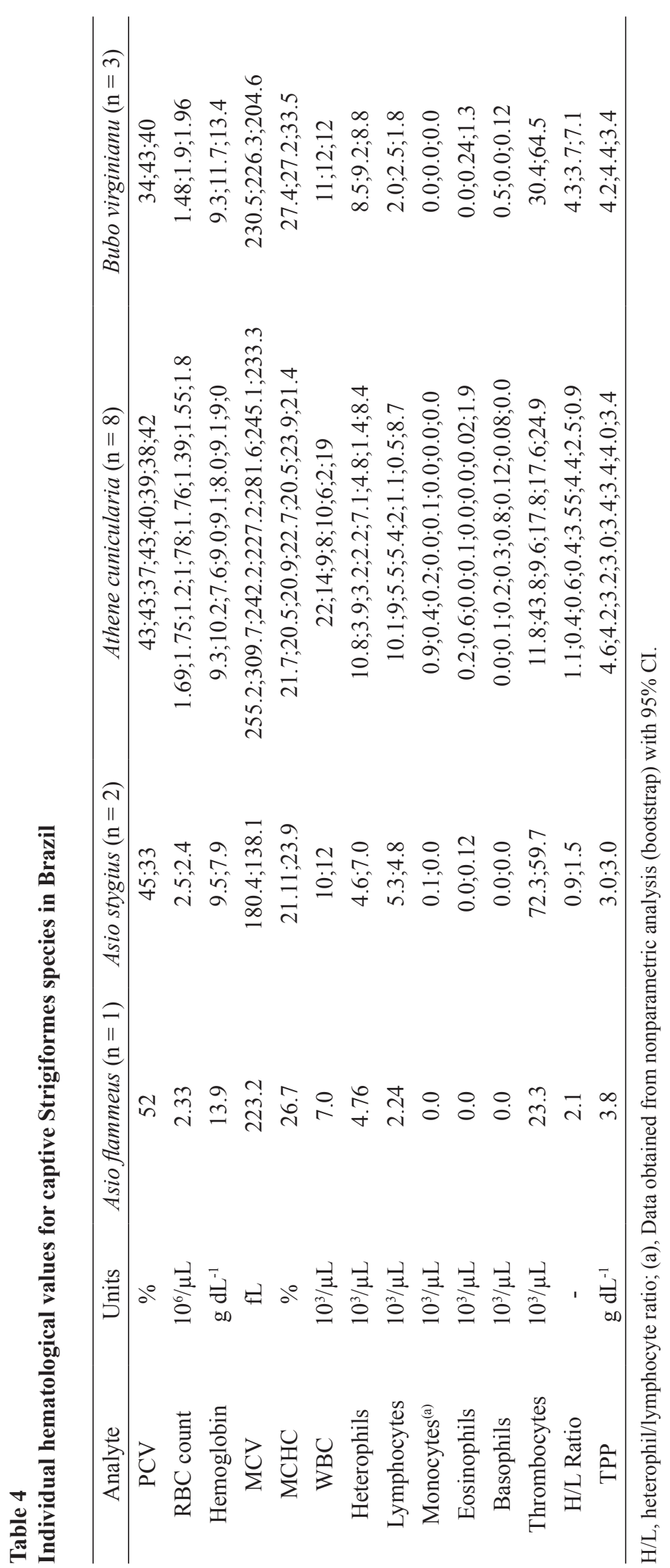


Table 5

Individual hematological values for captive Strigiformes species in Brazil

\begin{tabular}{ccccc}
\hline Analyte & Units & Pulsatrix koeniswaldiana $(\mathrm{n}=2)$ & Pulsatrix perspicillata $(\mathrm{n}=3)$ & Strix virgata $(\mathrm{n}=1)$ \\
\hline PCV & $\%$ & $38 ; 41$ & $40 ; 41.44$ & 29 \\
RBC count & $10^{6} / \mu \mathrm{L}$ & $1.5 ; 2.4$ & $1.38 ; 1.2 ; 1.2$ & 2.17 \\
Hemoglobin & $\mathrm{g} \mathrm{dL}^{-1}$ & $9.5 ; 12$ & $11.1 ; 10.3 ; 10.1$ & 12.9 \\
MCV & $\mathrm{fL}$ & $255.0 ; 171.9$ & $289.9 ; 341.7 ; 371.3$ & 133.64 \\
MCHC & $\%$ & $25 ; 29.6$ & $27.8 ; 25.1 ; 22 ; 9$ & 44.5 \\
WBC & $10^{3} / \mu \mathrm{L}$ & $10 ; 18$ & $19 ; 7 ; 11$ & 15 \\
Heterophils & $10^{3} / \mu \mathrm{L}$ & $5.3 ; 11.5$ & $10.4 ; 3.4 ; 4.8$ & 10.6 \\
Lymphocytes & $10^{3} / \mu \mathrm{L}$ & $1.8 ; 3.0$ & $3.2 ; 1.9 ; 3.0$ & 4.05 \\
Monocytes ${ }^{(\mathrm{a})}$ & $10^{3} / \mu \mathrm{L}$ & $0.0 ; 0.0$ & $0.02 ; 0.0 ; 0.0$ & 0.0 \\
Eosinophils & $10^{3} / \mu \mathrm{L}$ & $2.5 ; 3.2$ & $4.2 ; 1.5 ; 2.4$ & 0.0 \\
Basophils & $10^{3} / \mu \mathrm{L}$ & $0.4 ; 0.18$ & $0.9 ; 0.07 ; 0.6$ & 0.3 \\
Thrombocytes & $10^{3} / \mu \mathrm{L}$ & $25.3 ; 73.9$ & $30.3 ; 25.2$ & 19.5 \\
H/L Ratio & - & $2.9 ; 3.8$ & $3.2 ; 1.6 ; 1.6$ & 2.6 \\
TPP & $\mathrm{g} \mathrm{dL}^{-1}$ & $4.6 ; 5.2$ & $4.0 ; 4.2 ; 4.6$ & 4.8 \\
\hline
\end{tabular}

H/L, heterophil/lymphocyte ratio; (a), Data obtained from nonparametric analysis (bootstrap) with 95\% CI.

Table 6

Hematological and TPP values (mean \pm SD) for healthy Asio clamator adults according to sex, in Brazil

\begin{tabular}{ccc}
\hline Parameter & Female $(\mathrm{n}=5)$ & Male $(\mathrm{n}=13)$ \\
\cline { 2 - 3 } & Mean \pm SD & Mean \pm SD \\
\hline RBC $\left(10^{6} / \mu \mathrm{L}\right)$ & $1.6 \pm 0.3$ & $1.7 \pm 0.4$ \\
PCV $(\%)$ & $44 \pm 3.9$ & $40 \pm 3.9$ \\
Hemoglobin $\left(\mathrm{g} \mathrm{dL}^{-1}\right)$ & $12.2 \pm 1.6$ & $11.1 \pm 2.7$ \\
MCV $(\mathrm{fL})$ & $286.1 \pm 35.9$ & $238.8 \pm 52.7$ \\
MCHC $(\%)$ & $28.0 \pm 4.6$ & $28.0 \pm 6.7$ \\
WBC $\left(10^{3} / \mu \mathrm{L}\right)$ & $10.8 \pm 4.0$ & $11.3 \pm 5.4$ \\
Heterophils $\left(10^{3} / \mu \mathrm{L}\right)$ & $7.2 \pm 3.3$ & $7.5 \pm 4.3$ \\
Lymphocytes $\left(10^{3} / \mu \mathrm{L}\right)$ & $2.1 \pm 1.2$ & $2.8 \pm 1.4$ \\
Monocytes $\left(10^{3} / \mu \mathrm{L}\right)$ & $0.0 \pm 0.1$ & $0.1 \pm 0.2$ \\
Eosinophils $\left(10^{3} / \mu \mathrm{L}\right)$ & $1.1 \pm 0.5$ & $0.6 \pm 0.5$ \\
Basophils $\left(10^{3} / \mu \mathrm{L}\right)$ & $0.4 \pm 0.3$ & $0.2 \pm 0.3$ \\
H/L Ratio & $5.1 \pm 2.6$ & $3.4 \pm 2.3$ \\
TPP $(\mathrm{g} \mathrm{dL}-1)$ & $4.4 \pm 0.5$ & $3.9 \pm 0.4$ \\
\hline
\end{tabular}

H/L, heterophil/lymphocyte ratio.

Significantly higher values $(\mathrm{P}<0.05)$ of PCV No significant differences between other parameters were observed in females of Megascops spp. according to the birds' sex were observed. No (female $38.1 \pm 2.7 \%$; male $34.9 \pm 4.5 \%$ ) and $T$. morphological differences were found in RBC and furcata (female $45.6 \pm 2.8 \%$; male $42.3 \pm 3.3 \%$ ). WBC. 
No hemolysis or lipemia were detected in the samples analyzed.

Table 7

Hematological and TPP values (mean \pm SD) for healthy Megascops spp. adults according to sex, in Brazil

\begin{tabular}{ccc}
\hline Parameter & Female $(\mathrm{n}=17)$ & Male $(\mathrm{n}=7)$ \\
\cline { 2 - 3 } & Mean \pm SD & Mean \pm SD \\
\hline RBC $\left(10^{6} / \mu \mathrm{L}\right)$ & $1.5 \pm 0.3$ & $1.6 \pm 0.5$ \\
PCV $(\%)$ & $38.1 \pm 2.7^{\mathrm{a}}$ & $34.9 \pm 4.5^{\mathrm{b}}$ \\
Hemoglobin $\left(\mathrm{g} \mathrm{dL}{ }^{-1}\right)$ & $9.3 \pm 1.3$ & $9.5 \pm 1.8$ \\
MCV $(\mathrm{fL})$ & $262.3 \pm 55.8$ & $230.4 \pm 59.5$ \\
MCHC $(\%)$ & $24.6 \pm 4.0$ & $27.2 \pm 6.5$ \\
WBC $\left(10^{3} / \mu \mathrm{L}\right)$ & $12.4 \pm 6.0$ & $10.7 \pm 3.1$ \\
Heterophils $\left(10^{3} / \mu \mathrm{L}\right)$ & $5.9 \pm 2.3$ & $5.2 \pm 1.8$ \\
Lymphocytes $\left(10^{3} / \mu \mathrm{L}\right)$ & $5.1 \pm 3.3$ & $4.7 \pm 2.4$ \\
Monocytes $\left(10^{3} / \mu \mathrm{L}\right)$ & $0.2 \pm 0.2$ & $0.1 \pm 0.2$ \\
Eosinophils $\left(10^{3} / \mu \mathrm{L}\right)$ & $0.9 \pm 1.3$ & $0.5 \pm 0.9$ \\
Basophils $\left(10^{3} / \mu \mathrm{L}\right)$ & $0.2 \pm 0.3$ & $0.2 \pm 0.2$ \\
H/L Ratio & $1.7 \pm 1.5$ & $2.1 \pm 1.5$ \\
TPP $(\mathrm{g} \mathrm{dL}-1)$ & $4.1 \pm 0.5$ & $3.8 \pm 0.4$ \\
\hline
\end{tabular}

$\mathrm{H} / \mathrm{L}$, heterophil/lymphocyte ratio; Means on the same line with different superscripts are significantly different $(\mathrm{P}<0.05)$.

\section{Table 8}

Hematological and TPP values (mean \pm SD) for healthy Tyto furcata adults according to sex, in Brazil

\begin{tabular}{ccc}
\hline Parameter & Female $(\mathrm{n}=8)$ & Male $(\mathrm{n}=8)$ \\
\cline { 2 - 3 } & Mean \pm SD & Mean \pm SD \\
\hline RBC $\left(10^{6} / \mu \mathrm{L}\right)$ & $1.8 \pm 0.4$ & $1.9 \pm 0.4$ \\
PCV $(\%)$ & $45.6 \pm 2.8^{\mathrm{a}}$ & $42.3 \pm 3.3^{\mathrm{b}}$ \\
Hemoglobin $(\mathrm{g} \mathrm{dL}-1)$ & $11.5 \pm 1.7$ & $9.5 \pm 1.8^{*}$ \\
MCV $(\mathrm{fL})$ & $259.9 \pm 50.8$ & $230.7 \pm 50.4$ \\
MCHC $(\%)$ & $25.4 \pm 4.7$ & $22.4 \pm 3.08^{*}$ \\
WBC $\left(10^{3} / \mu \mathrm{L}\right)$ & $67.8 \pm 23.6$ & $50.0 \pm 15.3^{*}$ \\
Heterophils $\left(10^{3} / \mu \mathrm{L}\right)$ & $10.6 \pm 4.4$ & $11.3 \pm 4.4$ \\
Lymphocytes $\left(10^{3} / \mu \mathrm{L}\right)$ & $6.9 \pm 3.1$ & $7.6 \pm 4.1$ \\
Monocytes $\left(10^{3} / \mu \mathrm{L}\right)$ & $3.0 \pm 2.1$ & $3.1 \pm 1.4$ \\
Eosinophils $\left(10^{3} / \mu \mathrm{L}\right)$ & $0.1 \pm 0.2$ & $0.0 \pm 0.0$ \\
Basophils $\left(10^{3} / \mu \mathrm{L}\right)$ & $0.2 \pm 0.2$ & $0.1 \pm 0.1$ \\
H/L Ratio & $0.5 \pm 0.3$ & $0.5 \pm 0.4$ \\
TPP $(\mathrm{g} \mathrm{dL}-1)$ & $3.4 \pm 1.6$ & $3.6 \pm 2.9$ \\
\hline
\end{tabular}

H/L, heterophil/lymphocyte ratio; Means on the same line with different superscripts are significantly different $(\mathrm{P}<0.05) . * \mathrm{n}=7$. 


\section{Discussion}

This is the first report of a hematological and TPP database of captive healthy adult Strigiformes in three states of Brazil. One study reported hematological values of 89 captive owls belonging to seven species in the state of São Paulo (Zwarg, 2010).

Several factors influence hematological parameters: age, sex, species, diet, geographical conditions, stress situations, contention and circadian rhythm (García-Rodriguez, Ferrer, Carrillo, \& Castroviejo, 1987; Cray, 2015; Jones, Arheart, \& Cray, 2014). All birds in this study were adults kept in captivity with similar conditions of health, management and diet, so it was possible to generate accurate RIs and reference values. It is not advised to relate the values for Strigiformes with other raptors due to their own hematological characteristics and phylogenetic distance (Ammersbach et al., 2015a,b).

PCV may vary according to age, sex, altitude, energy expenditure, parasitism, nutrition and genetics (Artacho, Soto-Gamboa, Verdugo, \& Nespolo, 2007; Fair, Whitaker, \& Pearson, 2007; Campbell, Smith, \& Zimmerman, 2010). While the literature shows that males generally present higher values than females due to the effect of estrogen (Fair, Whitaker, \& Pearson, 2007; Campbell, 2012), the present study showed the opposite. Two species showed significant differences between mean PCV by gender: Megascops spp. and T. furcata, as observed in another study, which reported a slightly higher mean PCV for females than for males of Otus lettia (Chan, Lin, Chang, Wang, \& Hsu, 2012). However, some authors have reported that sex-related variation in raptors and other bird species is non-existent (Fair, Whitaker, \& Pearson, 2007; Campbell et al., 2010).

The PCV decreases on fasting in the first 2448 hours but is more intense after 28 days in Snow Goose (Anser caerulescens atlanticus; Lepage,
2015). The reason for that is the dependence of erythropoiesis on nutritional status (Artacho et al., 2007; Boismenu, Gauthier, \& Larochelle, 1992). A study involving common buzzard (Buteo buteo) reported no significant difference between PCV and hemoglobin levels on 13 fasting days. During the feeding period (13th to 21 st days), the parameters decreased, probably due to hemodilution caused by the total protein rise and colloid osmotic equilibrium (García-Rodriguez et al., 1987; Spagnolo, Crippa, Marzia, \& Sartorelli, 2006). Fasting seems to have no influence on PCV unless it is prolonged (Spagnolo et al., 2006; García-Rodriguez et al., 1987), and the PCV results of the present study show that the birds were adequately fed and that this issue did not influence the hematological parameters obtained, since they were similar to previous means observed in raptors (Campbell et al., 2010).

But the PCV values of the present study seem to be lower than the means reported in other research from Canada (Ammersbach et al., 2015a). PCV tends to be higher during winter in temperate regions, probably because of dehydration or the rise in oxygen demand by thermogenesis, molting or reproductive status (Fair, Whitaker, \& Pearson, 2007). Values higher than $55 \%$ are usually considered as polycythemia, caused by dehydration or increased production of erythrocytes (Fair, Whitaker, \& Pearson, 2007; Campbell, 1994). It has also been said that values of $50 \%$ are normal for some larger raptors (Campbell et al., 2010). The Brazilian regions where the samples were obtained in the present study have mostly subtropical weather, where seasons are not so well defined as in places with a temperate climate. So, the PCV values of birds in Brazil probably do not change because of the weather, but further studies are needed to evaluate this fact. Despite this, PCV values change for several reasons and the recommendation is not to use this parameter alone to define health status.

Mean HGB values found were often higher than in previous studies (Zwarg, 2010; Spagnolo, Crippa, 
Marzia, Alberti, \& Sartorelli, 2008; Szabo, Klein, \& Jakab, 2013), but none were too discrepant. The MCV of raptors is considerably higher than in mammals due to the presence of the cellular nucleus. It seems to have a difference between hawks and falcons versus eagles and owls. Both Falconiformes and Strigiformes show similar means, all above 200 fL (Campbell et al., 2010), which agrees with the findings of this study, except for $A$. stygius and $S$. virgata, which had MCV values between 130 and $180 \mathrm{fL}$.

The WBCs are usually similar between raptors, and eagles seem to have the highest values (Campbell et al., 2010). The present study showed smaller or similar means than those in the literature (Zwarg, 2010; Ammersbach et al., 2015a; Maceda-Veiga et al., 2015). The WBC counts may vary between rehabilitated, permanently captive or wildlife raptors (Ammersbach et al., 2015a). Besides that, data from the literature should be carefully compared because boreal species have smaller numbers of total leukocytes than in temperate/tropical regions (Ammersbach et al., 2015a).

The leukocyte differential counts rarely present normal distributions in Strigiformes even with high sample numbers; consequently, it does not allow the use of parametric techniques to report the values (Ammersbach et al., 2015a).

The $\mathrm{H} / \mathrm{L}$ ratio is widely used in vertebrate ecology studies and is related to the response of the innate immune system to stress level (Davis, Maney, \& Maerz, 2008). Other leukocytes have an important role too, and it is a great disadvantage disregard them (Maceda-Veiga et al., 2015). Species of the same genus tend to be lymphocytic or heterophilic (Ammersbach et al., 2015a). Some owl species are mostly lymphocytic, such as the genera Strix, Asio, Megascops asio and Aegolius acadicus (Ammersbach et al., 2015a). In the present study, almost all species presented $\mathrm{H} / \mathrm{L}$ ratios $>1$, except Megascops spp. (mean $\pm \mathrm{SD}=0.3 \pm 0.5)$.

Usually heterophils are in higher number than other types of leukocytes. However, higher numbers of lymphocytes in owls is reported; this disagrees with the values of most of the owl species found in this study (Campbell et al., 2010). Research conducted in the state of São Paulo showed that captive $M$. choliba, $P$. perspicillata and $S$. virgata were lymphocytic and A. cunicularia, A. clamator and T. furcata had more heterophils (Zwarg, 2010). In the present study, most of the species were heterophilic; however, Megascops spp. had some lymphocytic individuals, agreeing with studies in the literature (Zwarg, 2010; Ammersbach et al., 2015a)

In conclusion, this study established hematological RIs of one owl genus (Megascops spp.) and one owl species (A. clamator) and hematological descriptive statistic values for $T$. furcata in Brazil. Furthermore, individual values were determined for seven other Strigiformes species, which can help in the decision-making concerning clinical routine. Higher mean PCV values were found in females of Megascops spp and T. furcata, it being not necessary to differentiate the sex in the interpretation of the other hematological parameters for these two species.

This study was important in enhancing the laboratory diagnosis of owls in Brazil by considering different species and filling gaps existing in the literature.

\section{Acknowledgments}

We gratefully acknowledge the Zoológico Municipal de Canoas (Canoas, Rio Grande do Sul, Brazil), Zoológico Municipal Quinzinho de Barros (Sorocaba, São Paulo, Brazil), CETAS/PR and IBAMA/PR (Paraná, Brazil), Centro de Estudos do Mar - UFPR (Pontal do Sul, Paraná, Brazil), and PRESERVAS/UFRGS (Porto Alegre, Rio Grande do Sul, Brazil) for providing access to animals and assisting in the development of this project. 


\section{References}

Ammersbach, M., Beaufrère, H., Rollick, A. G., \& Tully, T. (2015a). Laboratory blood analysis in Strigiformes-part I: hematologic reference intervals and agreement between manual blood cell counting techniques. Veterinary Clinical Pathology/American Society for Veterinary Clinical Pathology, 44(1), 94108. doi: 10.1111/vcp.12229

Ammersbach, M., Beaufrère, H., Rollick, A. G., \& Tully, T. (2015b). Laboratory blood analysis in Strigiformes-Part II: plasma biochemistry reference intervals and agreement between the Abaxis Vetscan V2 and the Roche Cobas c501. Veterinary Clinical Pathology, 44(1), 128-140. doi: 10.1111/ vcp.12230

Artacho, P., Soto-Gamboa, M., Verdugo, C. \& Nespolo, R. F. (2007). Using haematological parameters to infer the health and nutritional status of an endangered black-necked swan population. Comparative Biochemistry and Physiology, 147(4), 1060-1066. doi: 10.1016/j.cbpa.2007.03.017

Boismenu, C., Gauthier, G., \& Larochelle, J. (1992). Physiology of prolonged fasting in greater snow geese (Chen Caerulescens Atlantica). The Auk, 109(3), 511-521. doi: 10.1093/auk/109.3.511.

Campbell, T. W. (1994). Hematology. In B. W. Ritchie, G. J. Harrison, \& L. R. Harrison (Eds.), Avian medicine: principles and application (pp. 176-198). Lake Worth, Florida: Wingers Publishing.

Campbell, T. W. (2012). Hematology of birds. In M. A. Thrall, G. Weiser, R. W. Allison, \& T. W. Campbell (Eds.), Veterinary hematology and clinical chemistry (pp. 238-276). Ames, Iowa: Wiley-Blackwell.

Campbell, T. W., Smith, S. A., \& Zimmerman, K. L. (2010). Hematology of waterfowl and raptors. In D. J. Weiss, \& J. Wardrop (Eds.), Schalm's veterinary hematology (pp. 977-986). Ames, Iowa: WileyBlackwell.

Chan, F. T., Lin, P. I., Chang, G. R., Wang, H. C., \& Hsu, T. H. (2012). Hematocrit and plasma chemistry values in adult collared scops owls (Otus lettia) and crested serpent eagles (Spilornis cheela hoya). Journal of Veterinary Medical Science, 74(7), 893898. doi: 10.1292/jvms.11-0521

Comitê Brasileiro de Registros Ornitológicos (2014). Listas das aves do Brasil. Comitê Brasileiro de Registros Ornitológicos. Recuperado de http://www. cbro.org.br

Cooper, J. E., \& Forbes, N. A. (1986). Studies on morbidity and mortality in the Merlin (Falco columbarius). The Veterinary Record, 118(9), 232235. doi: 10.1136/vr.118.9.232

Cray, C. (2015). Reference intervals in avian and exotic hematology. Veterinary Clinics of North America - Exotic Animal Practice, 18(1), 105-116. doi: 10.1016/j.cvex.2014.09.006

Davis, A. K., Maney, D. L., \& Maerz, J. C. (2008). The use of leukocyte profiles to measure stress in vertebrates: a review for ecologists. Functional Ecology, 22(5), 760-772. doi: 10.1111/j.1365-2435. 2008.01467.x

Fair, J., Whitaker, S., \& Pearson, B. (2007). Sources of variation in haematocrit in birds. Ibis, 149(3), 535552. doi: 10.1111/j.1474-919X.2007.00680.x

Friedrichs, K., Barnhart, K., Blanco, J., Freeman, K., Harr, K., Szladovits, B., \& Walton, R. (2010). Guidelines for the determination of reference intervals in veterinary species and other related topics. ASVCP Quality Assurance and Laboratory Standards Committee (QALS), 41(4), 1-33. doi: 10.1111/vcp. 12006

García-Rodriguez, T., Ferrer, M., Carrillo, J. C., \& Castroviejo, J. (1987). Metabolic responses of Buteo buteo to long-term fasting and refeeding. Comparative Biochemistry and Physiology, 87(2), 381-386. doi: 10.1016/0300-9629(87)90139-3

Geffré, A., Concordet, D., Braun, J. P., \& Trumel, C. (2011). Reference value advisor: a new freeware set of macroinstructions to calculate reference intervals with Microsoft Excel. Veterinary Clinical Pathology, 40(1), 107-112. doi: 10.1111/j.1939165X.2011.00287.x

Instituto Chico Mendes para Conservação da Biodiversidade (2008). Plano de ação nacional para a conservação de aves de rapina. Recuperado de http://www.icmbio.gov.br/portal/biodiversidade/ fauna-brasileira/plano-de-acao/2734-plano-de-acaonacional-para-a-conservacao-das-aves-de-rapina. html.

Ito, H., Sudo-Yamaji, A., Abe, M., Murase, T., \& Tsubota, T. (2003). Sex identification by alternative polymerase chain reaction methods in falconiformes sex identification by alternative polymerase chain reaction methods in falconiformes. Zoological Science, 20(3), 339-344. doi: 10.2108/zsj.20.339

Jones, M. P., Arheart, K. L. \& Cray, C. (2014). Reference intervals, longitudinal analyses, and index of individuality of commonly measured laboratory variables in captive bald eagles (Haliaeetus leucocephalus). Journal of Avian Medicine and Surgery, 28(2), 118-126. doi: 10.1647/2013-001 
Lepage, D. (2015). Avibase - the world bird database. Retrieved from http://avibase.bsc-eoc.org/avibase. jsp

Maceda-Veiga, A., Figuerola, J., Martínez-Silvestre, A., Viscor, G., Ferrari, N., \& Pacheco, M. (2015). Inside the redbox: applications of haematology in wildlife monitoring and ecosystem health assessment. Science of The Total Environment, 514, 322-332. doi: 10.1016/j.scitotenv.2015.02.004

Ministério do Meio Ambiente (2014). Portaria $N^{\circ} 444$, de 17 de dezembro de 2014. Recuperado de https:// www.icmbio.gov.br/portal/images/stories/docsplano-de-acao/00-saiba-mais/04_-_PORTARIA _MMA_N\%C2\%BA_444_DE_17_DE_DEZ $\overline{D E} 201 \overline{4}$.pdf

Santos, L. C., Cubas, P. H. (2017). Colheita e conservação de amostras biológicas. In Z. S. Cuba, J. C. R. Silva, \& J. L. Catão-Dias (Eds.), Tratado de animais selvagens - medicina veterinária (pp. 1554-1564). São Paulo, SP: Roca.

Spagnolo, V., Crippa, V., Marzia, A., \& Sartorelli, P. (2006). Reference intervals for hematologic and biochemical constituents and protein electrophoretic fractions in captive common buzzards (Buteo buteo). Veterinary Clinical Pathology, 35(1), 82-87. doi: 10.1111/j.1939-165x.2006.tb00092.x
Spagnolo, V., Crippa, V., Marzia, A., Alberti, I., \& Sartorelli, P. (2008). Hematologic, biochemical, and protein electrophoretic values in captive tawny owls (Strix aluco). Veterinary Clinical Pathology, 37(2), 225-228. doi: 10.1111/j.1939-165X.2008.00038.x

Szabo, Z., Klein, A., \& Jakab, C. (2013). Hematologic and plasma biochemistry reference intervals of healthy adult barn owls (Tyto alba). Avian Diseases, 58(2), 228-231. doi: 10.1637/10715-111013-Reg.1

Walberg, J. (2001). White blood cell counting techniques in birds. Seminars in Avian and Exotic Pet Medicine, 10(2), 72-76. doi: 10.1053/saep.2001.22051

Zinkl, J. G. (1986). Avian hematology. In N. C. Jain (Ed.), Schalm's veterinary hematology (4nd ed., pp. 256273). Philadelphia, Pennsylvania: Lea and Febiger.

Zwarg, T. (2010). Hematologia, pesquisa de hemoparasitos e mensuraçao da atividade de Colinesterases plasmáticas em Falconiformes e Strigiformes do estado de São Paulo, Brasil. Tese de doutorado, Programa de Pós-Graduação em Patologia Experimental e Comparada da Faculdade de Medicina Veterinária e Zootecnia, Universidade de São Paulo, São Paulo, SP, Brasil. 